\title{
Coordinate Suppression of Mutations Caused by RoberTson's Mutator Transposons in Maize
}

\author{
Robert Martienssen and Aimee Baron ${ }^{1}$ \\ Cold Spring Harbor Laboratory, Cold Spring Harbor, New York 11724 \\ Manuscript received August 12, 1993 \\ Accepted for publication November 29, 1993
}

\begin{abstract}
ABSTRAGT
Transposable elements from the Robertson's Mutator family are highly active insertional mutagens in maize. However, mutations caused by the insertion of responder (non-autonomous) elements frequently depend on the presence of active regulator (autonomous) elements for their phenotypic effects. The hcf106::Mu1 mutation has been previously shown to depend on $M u$ activity in this way. The dominant Lesion-mimic 28 mutation also requires $M u$ activity for its phenotypic effects. We have used double mutants to show that the loss of $M u$ activity results in the coordinate suppression of both mutant phenotypes. This loss can occur somatically resulting in large clones of cells that have a wild-type phenotype. Autonomous and non-autonomous Mutator elements within these clones are insensitive to digestion with methylation-sensitive enzymes, suggesting extensive methylation of CG and non-CG cytosine residues. Our data are consistent with the sectors being caused by the cycling of $M u D R$ regulatory elements between active and inactive phases. The pattern of sectors suggests that they are clonal and that they are derived from the apical cells of the vegetative shoot meristem. We propose that these cells are more likely to undergo epigenetic loss of $M u$ activity because of their longer cell division cycle during shoot growth. Coordinate suppression of unlinked mutations can be used to perform mosaic analysis in maize.
\end{abstract}

$\mathrm{T}$ HE phenotypic effects of mutations caused by the insertion of transposable elements are frequently influenced by factors that interact with the transposon (MCCLINTOCK 1965b; GIERL 1990; FEDOROFF 1989; BOEKE 1989; Hahn et al. 1989; RUTLEDGe et al. 1988; PARKHURST et al. 1988; WilliaMs et al. 1988; ROBERTSON and ENGELS 1989). These factors include transcription factors, transposase and other proteins required for transposition. In the absence of these factors, gene expression can sometimes be restored via transcriptional readthrough and splicing, or by relieving transcriptional interference, depending on where the element is inserted in the target gene. Transposable elements of the RoBERTSON's Mutator system are some of the most active and widely used mutagens in the maize genome (reviewed in BENNETZEN et al. 1993; CHANDLER and HARDEMAN 1992) and, as in other transposon systems, the phenotypic effects of $M u$ element insertion sometimes depend on transposon activity (MARTIENSSEN et al. 1990; LoWE et al. 1992; HAKE 1992; CHOMET et al. 1991; R. A. MARTIENSSEN and D. MCCARTY, unpublished results).

There are at least seven classes of $M u$ element, each of which shares similar 200-bp terminal inverted repeats, but whose internal sequences fail to cross-hybridize (BENNETZEN et al. 1993; CHANDLER and HARDEMAN 1992). Recently, one of these classes has been shown to include the regulatory autonomous transposon $M U D R$ (previously known as $M u R, M u A 2$, and $M u 9$ (CHOMET et al. 1991; QIN et al. 1991; HERSHBERGER et al. 1991)). The

\footnotetext{
${ }^{1}$ Present address: Oncogene Sciences Inc., 106 Charles Lindberg Bld. Uniondale, New York 11553.
}

$M u D R$ element encodes the functions required for transposition of the other $M u$ elements. Two transcripts are encoded by MuDR (CHOMET et al. 1991; HershBERGER et al. 1991). The loss of MuDR is correlated with the absence of these transcripts, and with the extensive cytosine-methylation of the responder $\mathrm{Mul}$ elements (Chandler and Walbot 1986; BenNetzen 1987). This methylation, and the loss of activity, are usually fully reversible by crossing plants that have lost activity back to active plants in "reactivation crosses" (MARTIENSSEN et al. 1990; BROWN and SUNDARESAN 1992), although dominant losses of $M u$ activity have been reported (WALBOT 1986; ROBERTSON 1983, 1986; BENNETZEN 1987).

In the case of the $h c f 106:: M u 1$ allele in maize, a $M u 1$ element has inserted near the transcription initiation site of a gene required for chloroplast development (MARTIENSSEN et al. 1989; BARKAN and MARTIENSSEN 1991). This results in failure to accumulate transcripts from the gene, and a pale-green seedling lethal phenotype. When $M u$ activity (i.e., $M u D R$ activity) is lost, gene expression is restored via an outward-reading promoter within the terminal inverted repeats of the $M u 1$ element (BARKAN and MARTIENSSEN 1991). This results in phenotypic suppression of the effects of the mutation. Three other mutations caused by the insertion of $M u 1$ elements in the promoter regions at the Kn1-0, al and $v p 1$ loci have also been shown to respond to $M u$ activity in a similar fashion (LOWE et al. 1992; CHOMET et al. 1991; R. A. MARTIENSSEN and D. MCCARTY, unpublished results). In addition, some dominant alleles at the 
Knotted 1 locus are caused by insertion of $M u 8$ and $M u 1$ elements into the third intron of the $K n 1$ gene, and these also depend on $M u$ activity for their phenotypic effects (B. GreEn, R. WALko and S. HAKE, personal communication). The molecular mechanism of phenotypic suppression in this case is not known (HAKE 1992).

In plants that undergo somatic loss of $M u$ activity, this loss can be visualized by variegation for the $h c f 106 \mathrm{mu}-$ tant phenotype (MARTIENSSEN et al. 1990). Variegated plants have a distinctive pattern of loss in which groups of phenotypically normal cells arise progressively during development of the plant. By comparison with the pattern of sectors induced by X-rays during embryogenesis (Poethig et al. 1986), it has been suggested that the groups of cells are clonal, and that they are derived from a few cells in the early embryo that are destined to contribute to the shoot apical meristem (MARTIENSSEN $e t$ al. 1990). Increased variegation is correlated with an increase in $M u 1$ methylation in the upper leaves of these and similar plants (BENNETZEN et al. 1988; MARTIENSSEN et al. 1990). This pattern contrasts with patterns of variegation induced by sister-strand exchange in ringchromosomes (McClinTock 1938; LANGDALE et al. 1989), or by transposon excision (e.g., BOSSINGER et al. 1992). These patterns do not change predictably with respect to the axis of the plant.

In maize, one of the best studied transposable element gene control systems is the Suppressor-mutator (Spm)/Enhancer (En) system (MCCunTOCK 1958, 1965a; PEterson 1966; Fedoroff 1983, 1989; GierL 1990). The cis- and trans-acting components required for phenotypic suppression or enhancement of Spm insertions at a given locus are well understood genetically and at the biochemical level (FrEY et al. 1990; GRANT et al. 1990; SCHLAPPI et al. 1993). In principle, two types of phenotypic variegation associated with Spm elements might be analogous to the pattern of variegation observed in plants homozygous for $h$ cf 106::Mu 1: "cycling" of autonomous elements between active and inactive phases (McClintock 1958; Peterson 1966) and "presetting" of gene expression patterns influenced by transposons at the locus (MCCLinTock 1964, 1965a). As with the Spm system (FEDOROFF 1983), these two possibilities can be distinguished in plants that carry two mutations whose phenotypic effects depend on transposon activity.

In this report we describe a dominant suppressible mutation that responds to ROBERTSON's Mutator activity, namely Les 28. Les (lesion-mimic) mutants mimic the hypersensitive response to pathogen infection by producing numerous chlorotic lesions on the leaf blade in the absence of pathogen attack (NEUfFER and CALVERT 1975). We show here that the Les 28 mutant phenotype is co-regulated with that of $h c f 106$ and depends on $M u$ activity in the same way. We have examined the pattern of somatic loss of mutant phenotype in double mutant hcf106, Les 28 plants, as well as the pattern of inherit- ance of this loss in subsequent generations. This analysis confirms that the somatic loss of $M u$ activity in $h c f 106$ plants is clonal and heritable, and allows us to distinguish between the "presetting" and "cycling" models. In the light of these observations, previously unexplained Mutator phenomena can be interpreted in terms of the inheritance of suppressible mutant phenotypes from variegated plants. The coordinate suppression of unlinked suppressible phenotypes also provides a powerful tool for mosaic analysis.

\section{MATERIALS AND METHODS}

Genetic stocks: The origin of the $h c f 106:: M u 1$ allele has been described previously (BARKAN et al. 1986; MARTIENSSEN et al. 1989). Les 28 arose in a reactivation cross between RM21-1 ( $M u$-on, $h c f 106 /+$ ), and RM31-6 (Mu-off $h c f 106 /$ hcf106). RM31-6 was heterozygous for the Les 28 allele, and was derived from AB45-13 ( $M u$-off, $h c f 106 /+)$ by selfpollination. RM31-6 and AB45-13 were phenotypically wildtype. $\mathrm{AB} 45-13$ was derived from $\mathrm{AB} 12-7$, also by selfpollination, and many of its siblings were phenotypically hef mutant, suggesting that $\mathrm{AB} 12-7$ had mostly active $M u$ gametes. This stock (from A. BARKAN) had been outcrossed three times to the inbred $\mathrm{B} 73$, and did not carry the Lesion-mimic mutation. Therefore the Les 28 mutation must have arisen late in a germ cell lineage of AB12-7, but was not expressed phenotypically in the next generation due to loss of $M u$ activity.

Seedlings (Tables 1-4) were grown in the greenhouse at $22-27^{\circ}, 16$-hr days. Metromix artificial soil was used. Mutant hcf seedlings were pale green, and typically died at 2-3 weeks after germination unless sectors of phenotypically wild-type tissue appeared in leaves $1-4$. Plants that were sectored only in later leaves would not have been scored as variegated, as these plants would die before the sectored leaves emerged. The lesion-mimic phenotype is enhanced by strong sunlight and low temperatures, and is difficult to score in field-grown seedlings because of insect damage. Sectors in mature plants were recorded by photography and/or by noting the first and last mosaic leaves below the tassel.

DNA extraction and Southern blotting: DNA was extracted from sectors according to MARTIENSSEN et al. (1990). DNA was digested overnight according to the manufacturer's recommendations at 5-10 units per microgram in the presence of spermidine $(2.5 \mathrm{~mm})$. Southern hybridization was as described (Martienssen et al. 1990), using Hybond-N (Amersham) filters, and UV cross-linking to immobilize the digested DNA. Complete digestion was assured by stripping the Southern filters and re-probing with maize chloroplast DNA probes (not shown; MARTIENSSEN et al. 1990).

\section{RESULTS}

Les 28 is a dominant, $M u$-dependent mutation: Les 28 arose as a new dominant mutation in a "reactivation" cross between a plant that was homozygous for $h$ cf 106 (and $M u$-off) and a plant that was heterozygous for $h c f 106$ (and Mu-on) (see MATERIALS AND METHODS). Plants carrying the new mutation had small, papery chlorotic lesions typical of lesion-mimic mutants, as well as occasional longer streaks of necrotic tissue (see Figure 1 ). It is not known whether pathogenic agents are required for this phenotype, but the mutation was found to respond to strong sunlight and low temperatures (i.e., 


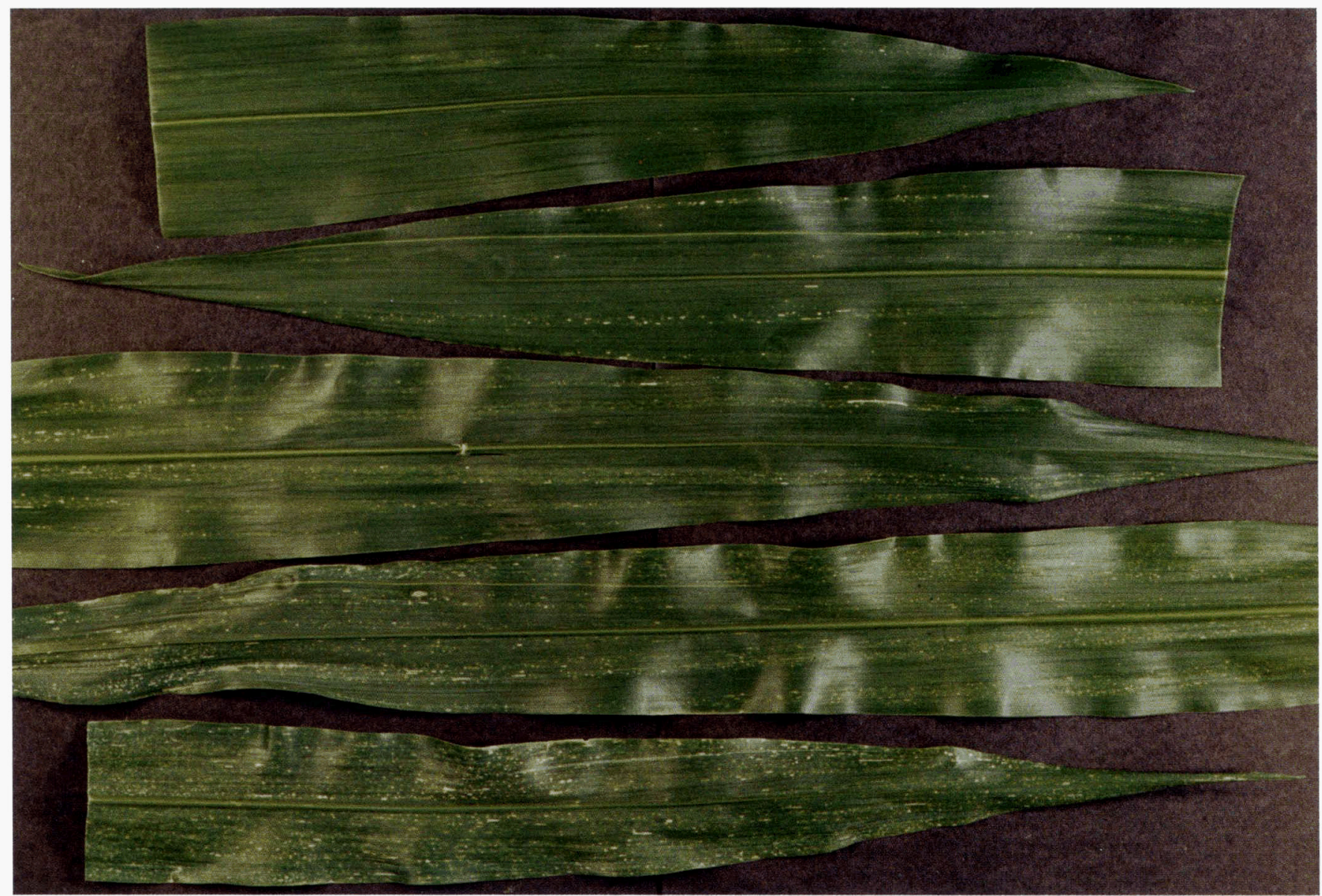

FIGURE 1.-The Les 28 mutant phenotype. Successive mature leaves (top to bottom, leaves $9-13$ below the tassel) from a Les $28 /+$ plant. Mutant lesion-mimic leaf tissue has a high density of papery chlorotic lesions that mimic the hypersensitive response to some pathogens. The lowest leaf is almost completely mutant, while the uppermost has only one small sector of mutant tissue.

summer field conditions ws. winter greenhouse) as reported for other lesion-mimic mutants (NEUFFER and CALVERT 1975). In crosses to lines that carried active $M u$ tator elements, the Les 28 mutation behaved as a simple Mendelian dominant unlinked to hcf106 (e.g., Table 1, cross 3). However, the mutation showed variable penetrance (e.g., Table 1 Cross 1), and when Les28/+ plants were crossed to non-Mutator lines or $M u$-offlines, the frequency of mutant plants was far lower than expected (not shown). Furthermore, plants that carried the Les 28 mutation usually gave no Les 28 progeny when self-pollinated (for this reason, Les $28 /$ Les 28 homozygotes have not been unequivocally identified genetically). This low penetrance in non-Mutator lines suggested that the Les 28 phenotype might be suppressed in plants that had lost Mutator activity, as had been previously shown for the $h c f 106$ phenotype (MARTIENSSEN et al. 1990). Confirmation of this hypothesis was obtained by examining co-inheritance of the two phenotypes somatically and germinally, as described below.

Les 28 and $h$ cf 106 are coordinately suppressed: $h c f 106$ is a seedling lethal non-photosynthetic mutation that has a pale green mutant phenotype due to a reduction in chlorophyll accumulation (BARKAN et al.
1986; MARTIENSSEN et al. 1989, 1990). In some families, $h c f 106 / h c f 106$ plants are variegated: progressively larger wild-type sectors appear on successive leaves until the upper leaves are normally pigmented, and the plants survive and are fertile (MARTIENSSEN et al. 1990). Based on the position and size of these sectors, they are likely derived from individual cells or groups of cells within the apical meristem that have lost $M u$ activity. Pollen from a variegated $h c f 106 / h c f 106$ plant was used to fertilize the ear from a Les $28 /+, h c f 106 /+$ heterozygous plant. Variegation for $M u$ activity is partly heritable (see later) so that variegated Les 28 plants would be recovered from this cross if the phenotype depended on $M u$ activity. As predicted, several variegated lesion-mimic plants were recovered: they displayed large sectors of leaf material that were essentially free of chlorotic lesions (Figure 1). These sectors passed from leaf to leaf in a manner suggesting that they arose as the clonal descendants of single meristematic cells: sectors near the margin of one leaf appeared close to the midrib of the next (Figure 1, and data not shown). The boundaries of these sectors were typically sharp, such that very high densities of lesions $\left(10-20\right.$ per $\left.\mathrm{cm}^{2}\right)$ bordered on sectors with very low densities (less than 0.1 per $\mathrm{cm}^{2}$ ). Some of the progeny 
TABLE 1

Inheritance of Les 28 and $h c f 106$

\begin{tabular}{|c|c|c|c|c|c|c|}
\hline Cross & & & $N$ & $h c f\left({ }^{*}\right)$ & $h c f L e s\left({ }^{*}\right)$ & Les \\
\hline 1 & $\begin{aligned} h c f /+ & \times \\
+/+ & \times \\
\text { Les/+, } h c f /+ & \times\end{aligned}$ & $\begin{array}{l}\text { Les } /+, h c f /+ \\
\text { Les/+, hcf/+ } \\
h c f /+\end{array}$ & $\begin{array}{l}84 \\
23 \\
26\end{array}$ & $\begin{array}{ll}6 & (0) \\
0 & \\
0 & \end{array}$ & $\begin{array}{l}3(1) \\
0 \\
0\end{array}$ & $\begin{array}{r}10 \\
3 \\
0\end{array}$ \\
\hline 2 & $\begin{aligned} h c f / & \times \\
+/+ & \times \\
\text { Les } /+, h c f /+ & \times\end{aligned}$ & $\begin{array}{l}\text { Les } /+, h c f /+ \\
\text { Les/+, hcf/+ } \\
h c f /+\end{array}$ & $\begin{array}{l}51 \\
51 \\
22\end{array}$ & $\begin{array}{ll}2 & (0) \\
0 & \\
1 & \end{array}$ & $\begin{array}{l}2(0) \\
0 \\
0\end{array}$ & $\begin{array}{r}13 \\
16 \\
1\end{array}$ \\
\hline 3 & $\begin{array}{r}h c f /+\times \\
+/+\times \\
\text { Les } /+, h c f /+\times\end{array}$ & $\begin{array}{l}\text { Les } /+, h c f /+ \\
\text { Les/+, hcf/+ } \\
h c f /+\end{array}$ & $\begin{array}{r}118 \\
21 \\
27\end{array}$ & $\begin{array}{rr}20 & (5) \\
0 & \\
2 & (1)\end{array}$ & $\begin{aligned} 17 & (5) \\
0 & \\
3 & (2)\end{aligned}$ & $\begin{array}{r}43 \\
8 \\
1\end{array}$ \\
\hline 4 & $\begin{array}{r}h c f /+\times \\
+/+\times \\
\text { Les } /+, h c f /+\times\end{array}$ & $\begin{array}{l}\text { Les } /+, h c f /+ \\
\text { Les } /+, h c f /+ \\
h c f /+\end{array}$ & $\begin{array}{c}112 \\
43 \\
\mathrm{ND}\end{array}$ & $\begin{array}{c}16 \quad(9) \\
0 \\
\text { ND }\end{array}$ & $\begin{array}{l}9(5) \\
0 \\
\text { ND }\end{array}$ & $\begin{array}{r}34 \\
9 \\
\text { ND }\end{array}$ \\
\hline \multicolumn{7}{|c|}{ Summary } \\
\hline & $\begin{array}{r}h c f /+\times \\
+/+\times \\
\text { Les/+, } h c f /+\times\end{array}$ & $\begin{array}{l}\text { Les } /+, h c f /+ \\
\text { Les/+, hcf/+ } \\
h c f /+\end{array}$ & $\begin{array}{r}365 \\
109 \\
75\end{array}$ & $\begin{array}{l}44(14) \\
0 \\
3 \quad(1)\end{array}$ & $\begin{array}{l}31(11) \\
0 \\
3(2)\end{array}$ & $\begin{array}{r}100 \\
36 \\
2\end{array}$ \\
\hline
\end{tabular}

In each cross (1-4), a single Les $28 /+, h c f 106 /+$ heterozygous plant was used as male or female parent in testcrosses to $h c f 106 /+$ and wild-type $+/+$ parents (these were derived by self-pollinating $M u$ on $h c f 106 /+$ plants). The female parent of each cross is listed first. $N$, total number of progeny that germinated; $h c f\left({ }^{*}\right)$, number of $h c f$ mutant progeny (number that were sectored in parentheses); $h c f L e s\left({ }^{*}\right)$, number of $h c f 106$ Les 28 double mutants (sectored in parentheses); Les, number of Les 28 mutant seedlings (sectored Les seedlings could not be scored because lesions were sparse at the seedling stage); ND, not determined.

were doubly mutant for $h c f 106$ and Les 28 , and these were transplanted into pots in the greenhouse. Most of the double mutants died at the seedling stage as expected, since $h c f 106$ is lethal. However, one double mutant had large wild-type sectors that rescued the lethal hcf106 phenotype. As this plant grew, the wild-type sectors increased in size and abundance on the upper leaves (Figure 2). Clearly, both the lesion-mimic phenotype and the $h c f 106$ pale green phenotype are coordinately expressed in mutant sectors, and are coordinately suppressed in wild-type sectors. This was true for both large and small wild-type and mutant sectors. Sibling plants that did not carry Les 28 , but were variegated for $h c f 106$, had no lesions in the mutant sectors (not shown). Several variegated double mutants have been observed among the progeny of similar crosses (Table 2), and in each case the chlorotic lesions were restricted to the pale green tissue, confirming that the two mutant phenotypes were coordinately expressed in somatic sectors.

Four siblings that were heterozygous for both Les 28 and $h c f 106$ were crossed to wild-type and heterozygous hcf106 plants (Table 1). All but one of these doubly heterozygous plants were sectored, and had lost the lesion-mimic phenotype entirely in the upper leaves. The one plant that retained the lesion-mimic phenotype in the upper leaves gave rise to the expected number of mutant progeny in the next generation (cross 3 ). The others lost the lesion-mimic phenotype in their upper leaves, and gave rise to fewer mutant progeny than expected (crosses 1, 2 and 4). In order to confirm that the Les 28 and $h c f 106$ mutations were controlled genetically in the same way, "reactivation" crosses were performed (MARTIENSSEN et al. 1990). One of the variegated double mutants from cross 3 (Table 1) was self-pollinated, and the progeny grown up. None of the progeny expressed either phenotype, and individual plants from among these were self-pollinated and reciprocally crossed to plants that were heterozygous for hcf 106 and carried active $M u$. The results are shown in Table 2. None of the progeny resulting from self-pollination of the suppressed plants displayed either mutant phenotype. Further, none of the progeny resulting from self-pollination of the $M u$ active hcf 106 heterozygotes showed the lesion-mimic phenotype. However, both phenotypes were found in the progeny of the reactivation crosses. The number of double mutants in the progeny ( $69 \mathrm{hcf}$, 71 hcfles, 58 Les) was consistent with the co-regulation of the two genes, even when penetrance of each individual mutation was low. Thus the two phenotypes are co-regulated both somatically and germinally.

DNA methylation in Les 28 hcf 106 double mutants: In previous studies, DNA from sectors of wild-type tissue in variegated $h c f 106$ plants was found to contain methylated $M u 1$ transposons, as well as methylated sequences flanking the Mul element at the hcf106 locus (MarTIENSSEN et al. 1990). DNA was prepared from sectors from Les $28 /+h c f 106 / h c f 106$ double mutant plants, digested with HinfI, and probed with the first two exons from the Hcf 106 locus (Figure 3). Four hybridizing fragments were observed. The lower two fragments are bounded by sites within the gene and were found in DNA from mutant and wild-type tissue. The upper two bands (arrows) were only found in DNA from phenotypically suppressed tissue. These fragments are diagnostic of modification at both the Hinfl sites within $M u 1$, and additional partial modification of the Hinfl site $100 \mathrm{bp}$ upstream of the insertion site, respectively (MARTIENSSEN et al. 1990). The corresponding 400bp 


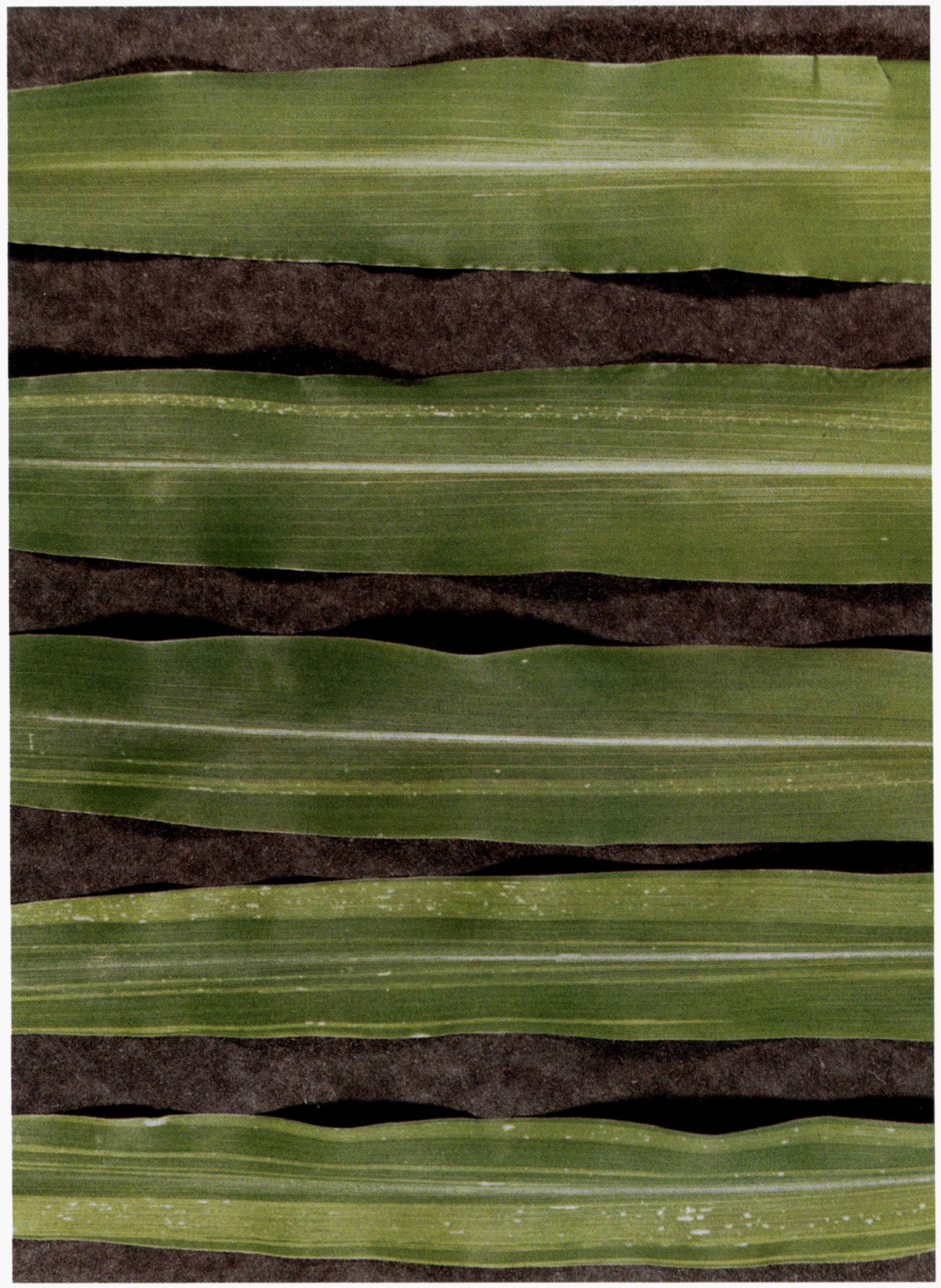

Figure 2.-Coordinate suppression of mutant phenotypes during development. Successive mature leaves (top to bottom, leaves $11-15$ below the tassel) from a $h c f 106 / h c f 106$ Les $28 /+$ double mutant. Sectors that have lost the hcf phenotype are dark green and have also lost the lesionmimic phenotype.

fragment from the unmethylated locus (MARTIENSSEN et al. 1990) has run off this gel. The correlation with wild-type phenotype and DNA methylation suggested that the sectors were derived from single cells or groups of cells in the shoot meristem that had lost $M u$ activity. In order to investigate the nature of this loss, DNA samples taken from sectors of a variegated double mutant were digested with a series of restriction enzymes and probed with an internal sequence from the regulatory transposon $M u D R$ (Figures 4 and 5). Sectors were derived from two successive leaves, and were probably independent judging by their positions on the leaf (not shown). The number of HindIII and XbaI fragments that hybridized to $M u D R$ was 15-20, consistent with the high level of Mutator activity in these lines (Figure 4). A similar result was obtained with EcoRI (data not shown). The pattern of hybridizing fragments with these deoxycytosine methylation-insensitive enzymes was very similar in DNA samples from sectors on the same leaf. In particular, no HindIII, XbaI or EcoRI fragments present in the mutant sectors were absent from the neighboring wildtype sectors. However, additional fragments were sometimes observed, particularly when comparing samples from different leaves (Figure 4, and data not shown).

The pattern of restriction fragments with the methylation-sensitive enzymes SstI and HpaII was strik- 
TABLE 2

Reactivation crosses

\begin{tabular}{|c|c|c|c|c|c|}
\hline Cross & & $N$ & $h c f(*)$ & $h c f L e s(*)$ & Les \\
\hline 1 & $\begin{aligned} h c f /+ & \times \text { Les/ } /, h c f / h c f \\
\text { Les/+, } h c f / h c f & \times h c f /+ \\
h c f /+ & \text { selfed } \\
\text { Les/+, } h c f / h c f & \text { selfed }\end{aligned}$ & $\begin{array}{l}81 \\
38 \\
\text { ND } \\
14\end{array}$ & $\begin{array}{l}9(3) \\
6(6) \\
\text { ND } \\
0\end{array}$ & $\begin{array}{c}13(7) \\
6(2) \\
\mathrm{ND} \\
0\end{array}$ & $\begin{array}{r}8 \\
8 \\
\mathrm{ND} \\
0\end{array}$ \\
\hline 2 & $\begin{aligned} h c f /+ & \times \quad \text { Les/+, } h c f / h c f \\
\text { Les/+, } h c f / h c f & \times h c f /+ \\
h c f /+ & \text { selfed } \\
\text { Les/+, } h c f / h c f & \text { selfed }\end{aligned}$ & $\begin{array}{l}78 \\
34 \\
21 \\
17\end{array}$ & $\begin{aligned} 21 & (2) \\
2 & (1) \\
5 & (0) \\
0 & \end{aligned}$ & $\begin{array}{l}14(3) \\
3(1) \\
0 \\
0\end{array}$ & $\begin{array}{r}12 \\
2 \\
0 \\
0\end{array}$ \\
\hline 3 & 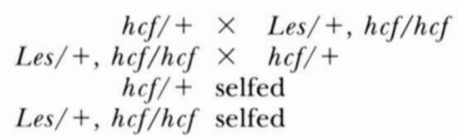 & $\begin{array}{l}39 \\
29 \\
24 \\
\text { ND }\end{array}$ & $\begin{array}{l}6(2) \\
0(0) \\
6(0) \\
\text { ND }\end{array}$ & $\begin{array}{l}4(3) \\
6(3) \\
0 \\
\text { ND }\end{array}$ & $\begin{array}{r}4 \\
3 \\
0 \\
\mathrm{ND}\end{array}$ \\
\hline 4 & $\begin{array}{c}h c f /+\times \quad \text { Les/+, hcf/hcf } \\
\text { Les/+,hcf/hcf } \times \quad \times \quad h c f /+ \\
h c f /+ \text { selfed } \\
\text { Les/+, hcf/hcf selfed }\end{array}$ & $\begin{array}{l}63 \\
41 \\
\text { ND } \\
17\end{array}$ & $\begin{array}{c}17(5) \\
7(2) \\
\mathrm{ND} \\
0\end{array}$ & $\begin{array}{c}18(2) \\
7(2) \\
\mathrm{ND} \\
0\end{array}$ & $\begin{array}{r}13 \\
2 \\
\text { ND } \\
0\end{array}$ \\
\hline
\end{tabular}

Each cross (1-4) was between a single heterozygous plant ( $h c f 106 /+, M u$-on) and a single homozygous $h c f 106$ plant (Mu-off) that was also heterozygous for Les28. In each case, the plants were crossed reciprocally and (where possible) self-pollinated on a second ear. Progeny were scored as in Table 1. ND, not determined.

ingly different (Figure 5). Recognition sites for both of these enzymes are found near the termini of the $M u D R$ element, and Southern blots show fragments of the predicted sizes corresponding to full-length (autonomous) MuDR elements (CHOMET et al. 1991; QIN et al. 1991; HERSHBERGER et al. 1991). In DNA from mutant sectors, two classes of multicopy $M u D R$-hybridizing fragments were observed in approximately equal numbers: fulllength elements (4.8-kb Sst $\mathrm{I}$ fragments), and a single class of $d M u D R$ deletion derivatives (Figure 5). In wildtype sectors, multiple larger fragments were also observed corresponding to failure to digest the majority of the $M u D R$ and $d M u D R$ elements. These fragments are likely to correspond to elements that have modified $S s t \mathrm{I}$ and HpaII sites. SstI is sensitive to methylation of the internal cytosine residue of its recognition site (GAGC*TC). This cytosine is not immediately followed by $\mathrm{G}$ or XG nucleotides, as are most 5-methyl $\mathrm{C}$ residues in plants (GRUenBaum et al. 1981).

Inheritance of suppressed phenotypes: Plants doubly marked with the two unlinked, but co-regulated $M u$ dependent mutations Les 28 and $h c f 106$ provide a tool to examine the inheritance of epigenetic changes in $M u$ regulatory elements, both somatically and germinally. According to the fate map of the apical meristem at the time of germination (JOHRI and COE 1982; MCDANIEL and Poethig 1988) the tassel arises from cells at the tip of the apical meristem, while the female inflorescence arises from the periphery nearer the base. In sectored plants carrying the $h c f 106$ and Les 28 mutations, leaves that arise from the tip of the apical meristem are more likely to have lost $M u$ activity than leaves that arise from the base. For this reason, it was previously suggested that $M u$ activity in mosaic plants might be more efficiently inherited via the female gametes than via the male

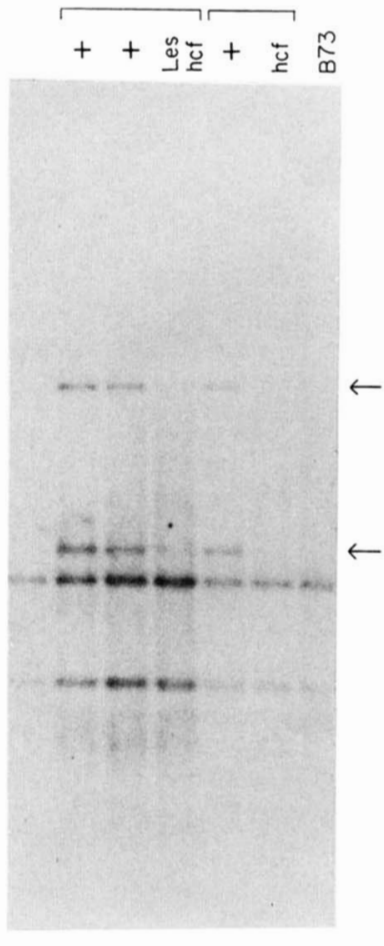

$\begin{array}{lllllll}1 & 2 & 3 & 4 & 5 & 6 & 7\end{array}$

FIGURE 3.-DNA from sectored plants is methylated at the hcf106 locus. DNA was isolated from phenotypically mutant and phenotypically wild-type sectors from $h c f 106 / h c f 106$ variegated plants, digested with HinfI, and subjected to Southern analysis using the first two exons of the Hcf106 gene as a probe (MARTIENSSEN et al. 1990). DNA was from the following: Lane 1 , a phenotypically mutant $h c f 106 / h c f 106$ seedling. Lanes 2 and 3, DNA from different sectors of normal tissue from the double mutant in Figure 2. Lane 4, DNA from a sector with mainly mutant tissue from the double mutant. Lane 5, DNA from normal tissue from a variegated $h c f 106 / h c f 106$ single mutant; Lane 6, DNA from mutant tissue from the single mutant. Lane 7, DNA from the inbred B73 (wild type). 


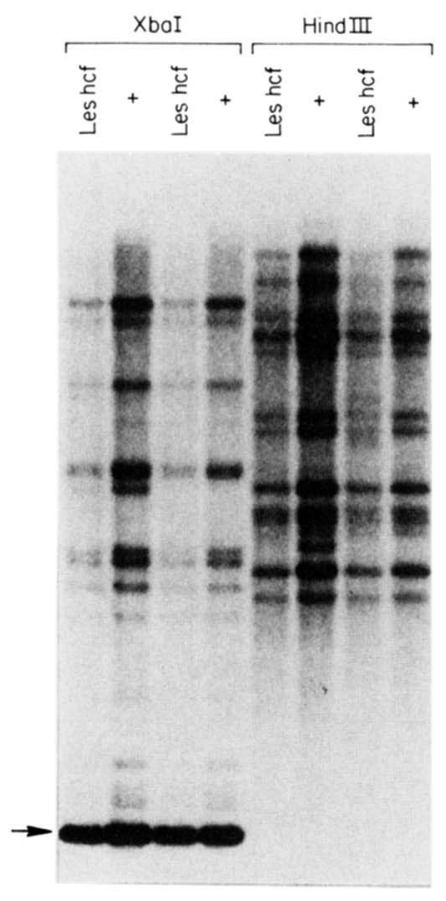

12345678

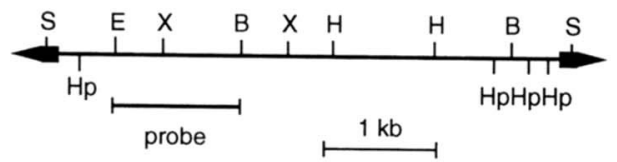

MuDR

FIGURE 4.-MuDR elements from sectored double mutants are not rearranged. DNA was isolated from mutant and phenotypically normal tissue from the 4 th (A) and the 5 th (B) leaf below the tassel of a double mutant Les $28 /+; h c f 106 / h c f 106$ plant (Leaf A: lanes 1, 2, 5, 6; Leaf B lanes 3, 4, 7, 8). The DNA was digested with $\mathrm{XbaI}$ (lanes 1-4) and HindIII (lanes 5-8), and subjected to Southern analysis using the internal EcoRI BamHI fragment from $M u D R$ as a probe (CHOMET et al. 1991). A strongly hybridizing $1.5-\mathrm{kb} X b a$ I fragment is internal to the $M u D R$ element (arrow). A restriction map of the $M u D R$ element is shown, along with the location of the probe. B, $B a m \mathrm{HI}$; E, EcoRI; X, XbaI; H, HindIII; Hp, HpaII; S, SstI.

(MARTIENSSEN et al. 1990). To test this hypothesis, sectored plants heterozygous for both Les 28 and $h c f 106$ were reciprocally crossed to homozygous, phenotypically suppressed $h c f 106$ plants. Only those progeny that inherited $M u$ activity from the sectored Les $28 /+$, $h c f 106 /+$ parent plant were capable of expressing the Les 28 and $h c f 106$ mutant phenotypes. For each parent plant, the leaf by which the lesion-mimic phenotype had completely disappeared, and the leaf at which $M u$-loss sectors were first observed, were recorded. Examples are shown in Table 3. In most of the crosses (Table 3 and data not shown), no inheritance of either phenotype was observed. However, in five crosses (crosses 4-8) mutant phenotypes were observed in the progeny. In two of them, only very few mutants were observed, and there was no significant difference between the reciprocal crosses (crosses 4 and 7). In the other three crosses, however, there was a very significant difference in the

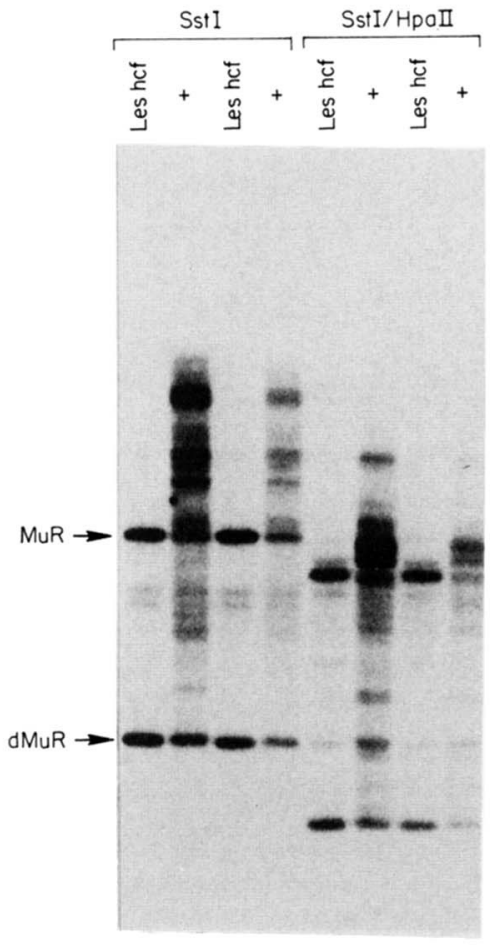

$\begin{array}{llllllll}1 & 2 & 3 & 4 & 5 & 6 & 7 & 8\end{array}$

FIGURE 5.-MuDR elements from sectored plants are modified. The same DNA samples as in Figure 4 were digested with Sst I (lanes 1-4), or SstI and HpaII (lanes 5-8). Sst I fragments from elements in mutant sectors fell into two size classes, 4.8 and $2.3 \mathrm{~kb}$ (arrows).

proportion of mutant progeny observed when $M u$ activity was transmitted through the female gametes rather than the male gametes. In crosses 5 and 6 , no activity was transmitted through the male, but substantial activity was transmitted through the female gametes: $21-22 \%$ of the progeny showed each mutant phenotype. As 50\% were expected to show each phenotype, this represents a penetrance of around $1 / 2$. In cross 8 , about $16 \%$ of the progeny from the ear displayed one or other mutant phenotype (a penetrance of $1 / 3$ ), while only $10 \%$ of the progeny from the pollen showed either phenotype (a penetrance of about $1 / 5$ ). The total number of hcf and Les mutant progeny in cross 8 was significantly different in reciprocal crosses at $P<1 \%$ (contingency chi-square).

It was postulated that these differences might reflect differences in the proportion of cells which retained $M u$ activity and contributed to each inflorescence. The partial penetrance might thus be explained by the ears in all three crosses, and the tassel in cross 8 , being mosaic for $M u$ activity. To test this, the progeny from each of the crosses in Table 3 were planted as an ear-map: each of the kernels was numbered, the ears were photographed to record the numbers, and then the kernels were planted and scored for lesion-mimic and hcf phenotypes. The phenotypes of the seedlings were recorded on the ear maps, which are shown in Figure 6. In each case a large region of the ear was identified that ap- 
TABLE 3

Reciprocal crosses using sectored plants

\begin{tabular}{|c|c|c|c|c|c|c|c|c|}
\hline \multirow[b]{2}{*}{ Cross } & & & \multirow[b]{2}{*}{$N$} & \multirow[b]{2}{*}{$h c f(*)$} & \multirow[b]{2}{*}{$h c f L e s\left({ }^{*}\right)$} & \multirow[b]{2}{*}{ Les } & \multicolumn{2}{|c|}{ Sectors } \\
\hline & & & & & & & Start & End $^{a}$ \\
\hline 1 & $\begin{array}{r}\text { Les/+, hcf/ }+\times \\
h c f / h c f \times\end{array}$ & $\begin{array}{l}h c f / h c f \\
h c f /+, L e s /+\end{array}$ & $\begin{array}{r}328 \\
20\end{array}$ & $\begin{array}{l}0 \\
0\end{array}$ & $\begin{array}{l}0 \\
0\end{array}$ & $\begin{array}{l}0 \\
0\end{array}$ & 9 & 4 \\
\hline 2 & $\begin{array}{r}\text { Les/+, hcfl }+\times \\
h c f / h c f \times\end{array}$ & $\begin{array}{l}h c f / h c f \\
h c f /+, \text { Les } /+\end{array}$ & $\begin{array}{l}511 \\
116\end{array}$ & $\begin{array}{l}0 \\
0\end{array}$ & $\begin{array}{l}0 \\
0\end{array}$ & $\begin{array}{l}0 \\
0\end{array}$ & 10 & 4 \\
\hline 3 & $\begin{array}{r}\text { Les } /+, h c f /+\times \\
h c f / h c f \times\end{array}$ & $\begin{array}{l}h c f / h c f \\
h c f /+, \text { Les } /+\end{array}$ & $\begin{array}{r}475 \\
24\end{array}$ & $\begin{array}{l}0 \\
0\end{array}$ & $\begin{array}{l}0 \\
0\end{array}$ & $\begin{array}{l}0 \\
0\end{array}$ & 7 & 2 \\
\hline 4 & $\begin{array}{r}\text { Les } /+, h c f /+\times \\
h c f / h c f \times\end{array}$ & $\begin{array}{l}h c f / h c f \\
h c f /+, L e s /+\end{array}$ & $\begin{array}{l}356 \\
210\end{array}$ & $\begin{array}{l}5(0) \\
0\end{array}$ & $\begin{array}{l}\mathrm{ND}^{b} \\
0\end{array}$ & $\begin{array}{r}\mathrm{ND}^{b} \\
0\end{array}$ & 8 & 1 \\
\hline 5 & $\begin{array}{r}\text { Les } /+, h c f /+\times \\
h c f / h c f \times\end{array}$ & $\begin{array}{l}h c f / h c f \\
h c f /+, \text { Les } /+\end{array}$ & $\begin{array}{l}250 \\
266\end{array}$ & $\begin{array}{l}34(19) \\
0\end{array}$ & $\begin{array}{c}22(8) \\
0\end{array}$ & $\begin{array}{r}35 \\
0\end{array}$ & 2 & \\
\hline 6 & $\begin{array}{r}\text { Les } /+, h c f /+\times \\
h c f / h c f \times\end{array}$ & $\begin{array}{l}h c f / h c f \\
h c f /+, \text { Les } /+\end{array}$ & $\begin{array}{l}375 \\
304\end{array}$ & $\begin{array}{r}38(3) \\
0\end{array}$ & $\begin{array}{c}43(3) \\
0\end{array}$ & $\begin{array}{r}38 \\
0\end{array}$ & 2 & \\
\hline 7 & $\begin{array}{r}\text { Les } /+, h c f f+\times \\
h c f / h c f \times\end{array}$ & $\begin{array}{l}h e f / h c f \\
h c f /+, \text { Les } /+\end{array}$ & $\begin{array}{l}373 \\
277\end{array}$ & $\begin{array}{l}6(0) \\
2(0)\end{array}$ & $\begin{array}{l}\mathrm{ND}^{b} \\
0\end{array}$ & $\begin{array}{r}\mathrm{ND}^{b} \\
8\end{array}$ & 4 & 1 \\
\hline 8 & $\begin{array}{r}\text { Les } /+, h c f /+\times \\
h c f / h c f \times\end{array}$ & $\begin{array}{l}h c f / h c f \\
h c f /+, \text { Les } /+\end{array}$ & $\begin{array}{l}127 \\
291\end{array}$ & $\begin{array}{l}10(1) \\
14(9)\end{array}$ & $\begin{array}{r}9(1) \\
13(8)\end{array}$ & $\begin{array}{l}12 \\
19\end{array}$ & 1 & \\
\hline
\end{tabular}

Each cross (1-8) was between a single heterozygous Les $28 /+, h c f 106 /+$ plant and a single homozygous $h c f 106$ plant (Mu-off). The plants were crossed reciprocally. Progeny were scored as in Table 1.

${ }^{a}$ The number of leaves below the tassel at which the first sector of phenotypically wild-type tissue appeared during development (start), and the last phenotypically mutant tissue was observed (end). Leaves above this point were phenotypically wild-type. The ear was subtended in most plants by the 8 th leaf below the tassel.

${ }^{b}$ Lesions were difficult to score in these crosses because of insect damage.

TABLE 4

Inheritance of sectoring

\begin{tabular}{lcccccc}
\hline Cross & Mu-off & Mu-on & $N$ & $h c f\left({ }^{*}\right)$ & $h c f L e s\left({ }^{*}\right)$ & Les \\
\hline 1 & Les $/+, h c f / h c f \times$ & $h c f /+$ & 78 & $21(7)$ & $19(7)$ & 8 \\
2 & Les $/+, h c f / h c f \times$ & $h c f /+$ & 75 & $27(3)$ & $10(1)$ & 7 \\
3 & $h c f / h c f \times$ & $h c f /+$ & 75 & $36(6)$ & 0 & 0 \\
4 & $h c f / h c f \times$ & $h c f /+$ & 80 & $30(8)$ & 0 & 0 \\
\hline
\end{tabular}

Pollen from the same plant ( $h c f 106 /+)$ was used to fertilize ears from four different homozygous $h c f 106$ ( $M u$-off) plants. Two of the $h c f 106 / h c f 106$ plants were also heterozygous for Les 28 .

peared to have lost both phenotypes. To test whether this group of kernels might have lost $M u$ activity, DNA was prepared from seedlings derived from a double ring of kernels that encircled one of the ears through the middle of the sector. The DNA was digested with HinfI and probed with $M u 1$, and the results are shown in Figure 7. The seedlings from most of the ear had primarily unmethylated $M u 1$ elements, suggesting they had retained $M u$ activity. However, the seedlings from within the sector had methylated elements suggesting they had lost $M u$ activity. This result suggests that the ear shoots were mosaic for $M u$ activity, and accounts for the partial penetrance observed.

\section{DISCUSSION}

Phenotypically suppressible mutations arise at a high frequency in ROBERTSON's Mutatorlines: we have observed several new mutants of this type affecting leaf pigmentation or morphology in our Mustocks. Many other mutants have also been reported (L. SMTTH and S. HAKE, personal com- munication; A. BARKAN, personal communication; J. Colasanti, M. Frefing and V. Sundaresan, Maize Coop. Newsl. 64, 39, 1990). Mutations can often be identified as suppressible because of the characteristic pattern of variegation observed in the leaves. Variegated plants have large nonmutant sectors that progressively increase in size and frequency during development. The presence of these sectors correlates with Mul methylation (MARTIENSSEN et al. 1990). One of these suppressible mutations, Les28, has been analyzed in detail here, and used to study the inheritance of suppressible phenotypes in ROBERTSON's Mutatorlines. We have shown that two unlinked suppressible mutations are coordinately regulated both genetically and during development. First, we have shown that inheritance of Les 28 closely follows the inheritance of another suppressible mutation, $h$ f 106 . As shown in Tables 1 and 2, the penetrance of the two mutations is similar in a given cross although it varies between crosses (varying from $\frac{1}{4}$ to nearly 1 ). In each cross, the ratio of hcf to lesion-mimic hcf double mutants is approximately $1: 1$, even when the penetrance of the individual mutations is low (compare Table 1, crosses 2 and 3). This suggests that expression of the two mutations are under the control of the same, unlinked genetic factor(s). Second, variegated lesion-mimic hcf double mutant plants coordinately lose both phenotypes in the non-mutant sectors, suggesting that the variegating factor acts in trans. A good candidate for the trans-acting factor in each case is the autonomous $M u D R$ regulatory element.

We considered two types of model to explain the variegation patterns observed, namely the "cycling" and "presetting" phenomena described for $S p m$ by 

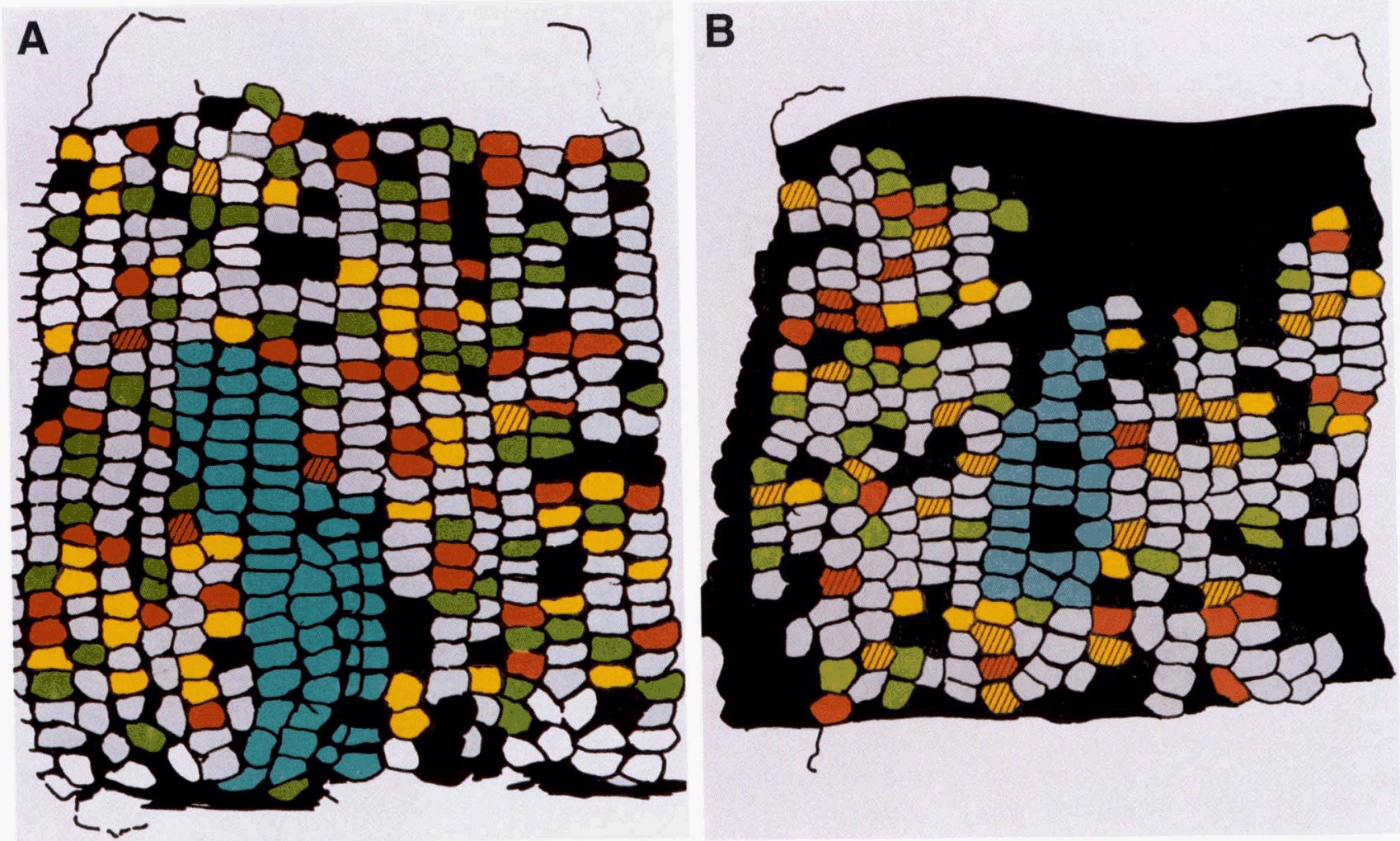

FiguRE 6.-The distribution of mutant progeny on mosaic ears. Plants heterozygous for Les 28 and $h c f 106$ were crossed by $h c f 106 / h c f 106$ (Mu-off) pollen parents [Table 3, crosses 5 (B) and 6 (A)]. Each kernel on the resulting ear was numbered, and the ear was photographed to record the numbers. The kernels were then planted according to number and scored for mutant phenotype. The position corresponding to each phenotype has been color coded as follows. Unfertilized kernels and those that failed to germinate are black, $h$ cf106 single mutants are yellow, Les 28 mutants are green and double mutants are orange. Variegated $h c f 106$ seedlings are indicated by cross-hatching. A large sector of kernels on each ear that failed to express either mutant phenotype is indicated in blue. Other kernels that gave rise to normal seedlings are white.

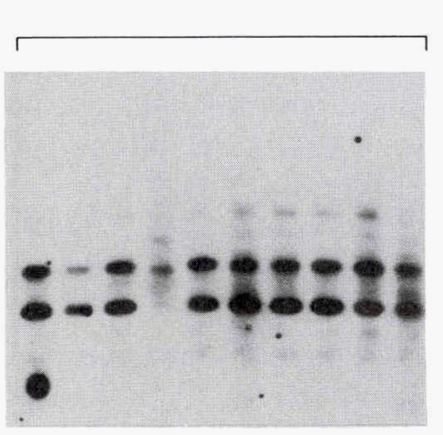

$\begin{array}{llllllllll}1 & 2 & 3 & 4 & 5 & 6 & 7 & 8 & 9 & 10\end{array}$

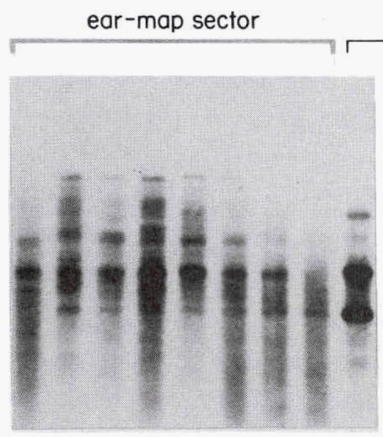

$\begin{array}{lllllllll}11 & 12 & 13 & 14 & 15 & 16 & 17 & 18 & 19\end{array}$

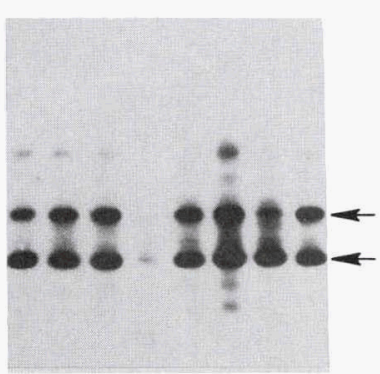

$20 \quad 2122 \quad 23 \quad 24252627$
Figure 7.-The distribution of methylated Mul elements in seedlings from mosaic ears. DNA was prepared from seedlings that germinated from a double ring of kernels that completely encircled the ear in Figure $6 \mathrm{~A}$. The DNA was digested with HinfI and subjected to Southern analysis using the complete $M u 1$ element as a probe. Seedlings 11-18 were from within the sector that had lost $M u$ activity and had methylated Mu 1 elements.
McGintock. Cycling Spm elements alternate between active and inactive phases during development. These changes of phase occur in clonal sectors and groups of cells, giving rise to variegated patterns (MCCLINTOCK 1958, 1968; Peterson 1966). Phases of activity and inactivity, although typically unstable, can be inherited over several generations (McCLINTOCK 1965a; FEDOROFF 1983, 1989). "Preset" patterns of expression are also variegated, but these patterns can be conditioned by nonautonomous elements (McCLinTock 1964, 1965a). Preset patterns depend on the presence of an autonomous element in a previous generation, and typically arise in the generation immediately following autonomous element loss, either by segregation or by transposition (McClintock 1965a, 1968). Such patterns are essentially nonheritable, though with interesting exceptions (McClintock 1964, 1965a).

McCLinTock could distinguish between presetting and cycling patterns in stocks that carried various derivative alleles of $a 1-m 1, a 1-m 2$ and $w x-m 8$, and that also carried an unlinked autonomous $S p m$ element. Derivative alleles (states) of $a 1-m 1$ have a defective $S p m$ element inserted near the splice donor site of the second intron of the $A 1$ gene required for anthocyanin forma- 
tion in the aleurone (SCHWARZ-SOMMER et al. 1987), while derivative alleles of $a 1-m 2$ have a defective $S p m$ element inserted into the promoter region of the same gene (MASSON et al. 1987; SCHWARZ-SOMMER et al. 1987). $w x-m 8$ has a defective $S p m$ inserted into an intron of the waxy endosperm gene (SCHWARz-SOMmer et al. 1984). When it is brought under the control of an unlinked cycling Spm, a1-m1 (state 5719A1) conditions variegated pigmentation of the aleurone layer, comprising large weakly pigmented sectors on a non-pigmented (but mutable) background. In $a 1-m 1$ (5719A1), wx-m 8 double mutants, endosperm tissue underlying the aleurone is also mutable for waxy, except in those regions underlying the weakly pigmented aleurone sectors. Endosperm tissue underlying these sectors is uniformly waxy. This is because $a 1-m 1$ and $w x-m 8$ are both under the control of the same unlinked $S p m$ element in clonally related sectors of the aleurone and the underlying endosperm (MCCLINTOCK 1958; FEDOROFF 1983). Similarly, in heterozygotes for two different states of $a 1-m 2$ ( 8004 and 7995), coordinate sectors can be discerned in which each allele has responded to changes in phase of an unlinked cycling $S p m$ in the same cells (MCCLINTOCK 1968). In contrast, "preset" patterns of $A 1$ expression occur in $a 1-m 2$ (7995) kernels that have lost $S p m$ by segregation at meiosis. These kernels retain no residual Spm activity, as demonstrated by the complete loss of mutability at $w x-m 8$ (MCCLINTOCK 1964, 1965a). In addition to these genetic tests, the variegated patterns conditioned by changes of phase and by presetting could be readily distinguished phenotypically (McClintock 1968).

By analogy, the $M u$ sectoring phenomenon we have observed reflects the developmental loss of (cycling) autonomous $M u$ activity, rather than retention of preset patterns of gene expression at the marker loci. This is because: (1) two unlinked loci are coordinately affected in the same sectors, and (2) changes in gene expression are heritable through meiosis and in subsequent generations. Two observations at the molecular level support this interpretation. Firstly, both $M u 1$ and $M u D R$ elements remain unmethylated in the mutant sectors in variegated plants, while both classes of element are extensively methylated in the non-mutant sectors. This methylation is indicative of the loss of $M U D R$ activity only in non-mutant sectors. Secondly, different $M u D R$ restriction fragments were observed in different leaves of the same variegated plant. This suggests that transposition is still occurring, and so $M u D R$ is still active in the mutant sectors of variegated plants. However, no $M u D R$ element present in mutant sectors is lost from non-mutant sectors on the same leaf. This suggests that, in the cases examined, the loss of transposase activity is not due to any large scale rearrangement in one or a few autonomous $M u D R$ elements. Losses due to rearrangement have been observed in stocks carrying a single
MuDR element, which undergoes frequent internal deletion (D. LISCH, P. CHOMET and M. FreELING, manuscript submitted for publication).

We conclude that the variegation of hcf and lesionmimic phenotypes is due to the epigenetic loss of MuDR activity during development, a loss that is correlated with the extensive methylation of $M u D R$ elements and their derivatives in the genome. Similar correlations between DNA methylation and inactivity have been observed for cycling Spm (BANKS and FEDOROFF 1989) and Acelements (CHOMET et al. 1987). Interestingly, the cytosine residues affected in $M u D R$ are not always part of $\mathrm{CpG}$ or $\mathrm{CpXpG}$ dinucleotides (Figure 5 ): the sequence immediately surrounding the Sst I site in MuDR (TTGGAGCTCCTT), for example, has no CG or CXG di- and trinucleotides (HershberGer et al. 1991). Non-CG or CXG cytosine methylation has been previously observed in maize transposable elements (SchWARz 1989; MCCARTY et al. 1989; WALBOT 1992), and these observations suggest that transposon methylation is not exclusively maintained by "maintenance" methyltransferase activity, but rather has to be imposed on the newly replicated unmethylated strand $d e$ novo at each cell division. This has consequences (see later) for models that involve the role of methyltransferase and other transacting proteins in maintaining or initiating the inactive state (HOLLIDAY 1987; SCWARTZ 1989; BANKS and FEDOROFF 1989; SELKER 1990).

The coordinate suppression of two unlinked $M u$ induced mutations provides a simple and powerful method for mosaic analysis. If the cell layer or cell types are known in which a given suppressible mutation acts, then double mutants with a second suppressible mutation will only give coordinate sectors if the cell layer in which the second product is required is the same. If the layer (or lineage) is different, sectors of one phenotype will overlap, or be distinct from sectors of the other phenotype. For example, the $h c f 106$ mutant effects chlorophyll pigmentation, and the gene product is found in the photosynthetic cells of the leaf (A. YoNETANI, L. DOLAN, A. BARON and R. MAR'TIENSSEN, unpublished data), which are primarily subepidermal. The Lesionmimic 28 gene product must be required in the same cell layer in order for all sectors to be coordinate. This suggests that the Les 28 gene product is required in the subepidermal rather than the epidermal layer. Such a conclusion could be confirmed by making double mutants with a second suppressible mutation that acts in the epidermal layer (such as a 1 -mum2, СHOMEт et al. 1991). In this case, non-coordinate sectors are expected. This method has advantages over classical methods that make use of radiation-induced terminal deficiencies to uncover linked markers (HAKE and FreELING 1986). First, linkage to the marker is not required; second, several unlinked markers can be used at the same time; and thirdly, sectors arise throughout development so that late and early events can be studied. A major limitation 
is that a $M u$-suppressible allele of the mutation under study is required, although suppressible alleles appear to arise at a high frequency in $M u$ lines (see earlier).

The inheritance of suppressed phenotypes was investigated by planting the progeny of Les $28 /+, h c f 106 /+$ plants in a manner that represents their location on the ear (an ear-map: COE 1961; ROBERTSON 1980). In several cases, large sectors of seedlings that had lost both the hef and the lesion-mimic phenotypes could be discerned on the map. These sectors had lost $M u$ activity, judging by the extensive methylation of $M u l$ elements in seedlings from within the sectors. Thus these ears were mosaic for $M u$ activity, and this activity was inherited through the female gametes derived from active sectors. Ear sectors that had lost $S p m$ activity have also been observed in plants carrying cycling $S p m$ at $c 1-m 5$ (B. McCuINTOCK, personal communication) or elsewhere in the genome (MCCLINTOCK 1964). Ears that are mosaic for Mutator activity provide a possible explanation for some of the ear sectors observed by ROBERTSON (1980). In these studies, plants carrying new mutations were frequently found in clusters on the ears of $F_{1}$ plants from Mutator $\times$ nonMutator crosses (ROBERTSON 1980). Many of these clusters were probably due to the induction of late, but premeiotic mutations, as originally proposed (ROBERTSON 1980). However, most of the clusters included kernels that carried non-allelic mutations, inconsistent with this model. If the $F_{1}$ plants were mosaic for $M u$ activity, then ear sectors of $M u$ active kemels could give rise to the observed clusters of non-allelic new mutations. The surrounding kernels could not carry new mutations, because they had lost Mutator activity. If some of these mutations were also suppressible, then the surrounding kernels would give rise to phenotypically wild-type seedlings regardless of their genotype, because of suppression. For example, the ear in cross 4 , Table 3 , had only five phenotypically mutant $h c f 106$ progeny, four of which were found in a small cluster near the tip of the ear (not shown). In one out of eight clusters identified by RoBertson (1980), the mutant phenotype found within the cluster was not transmitted to the $F_{3}$ generation, suggesting that this (pale green) mutation might belong to the suppressible class.

Sectored plants that lost $M u$ activity relatively late in development (just before emergence of the tassel) displayed a pronounced reciprocal effect in the inheritance of suppressible phenotypes (and hence $M u$ activity) from ear and tassel (Table 3). More mutant progeny were derived from the female rather than the male gametes of such plants. In contrast, sectored plants that lost activity earlier in development failed to transmit the mutant phenotype altogether. These observations are consistent with our earlier model for non-reciprocal transmission of Mutator activity in maize. According to this model, the transmission of $M u$ activity depends upon the position of the flower relative to the gradient of sectors observed in each plant (MARTIENSSEN et al. 1990): the tassel arises from the tip of the shoot apex, and is less likely to retain active $M u$ than the ear, which arises from the periphery of the apex further down the plant. Because of seedling lethality, only early losses could be observed using the hefl 106 mutation, so that this model could not be tested directly. In this study, however, the use of the Les 28 mutation has enabled visualization of this gradient in mature plants, and has confirmed that transmission of $M u$ activity from a given plant depends on how early the plant loses activity during development. Interestingly, several plants that had sectored lesion-mimic leaves well above the ear transmitted little or no activity through their female gametes (Table 3). Thus further losses must have occurred after emergence of the ear shoot from the main shoot axis. These losses are not easily monitored using the Les 28 mutation.

The sectoring phenotype itself may be heritable (the number of hcf progeny that were sectored are given in parentheses in Tables 1-4). One possibility is that the sectoring phenotype was inherited from the $M u$ active parent. In support of this idea, the proportion of variegated progeny in Table 2 was higher in crosses that had low penetrance: for example, crosses 1 and 3 gave $\frac{1}{4}$ hcf progeny, half of which were sectored, while crosses 2 and 4 gave 1/2 hcf progeny, less than $1 / 4$ of which were sectored. If there were two independently cycling autonomous $M u D R$ elements in the active line used, then the $h c f 106 /+$ parents in crosses 1 and 3 might have had only one cycling $M u D R$ element, while those in crosses 2 and 4 might have had both cycling $M u D R$ elements. If both elements must be inactive in order to result in phenotypic suppression of $h c f 106$, early sectors might only occur in seedlings that have one or the other $M u D R$ element, but not both. A similar type of "dosage" effect is observed when multiple cycling $S p m$ elements are introduced into the same kernel (McCLINTOCK 1958, 1968; FEDOROFF 1983). However, this model would predict that all of the seedlings in crosses 1 and 3 should be sectored, while only half of them were. Furthermore, reciprocal crosses between the same two plants differed widely in the proportion of homozygous hcf106 progeny that were sectored. For example, in cross 8 Table 3, sectored progeny appeared in greater numbers when the $M u$ active plant was used as the male $(17 / 27)$ than when it was used as the female $(2 / 19)$. This was also true of the reciprocal crosses in Table 2, and in other similar crosses (data not shown). Another possibility is that sectoring was inherited from the $M u$-off parent. For example, in Table 2, the $M u$-off parents were all the progeny of a sectored double mutant $h c f 106 / h c f 106$ Les $28 /+$ plant, and a high proportion of their progeny were also sectored in reactivation crosses $(52 \%, 18 \%, 50 \%$ and $22 \%$, respectively). This contrasts with the number of sectored hcf progeny observed in multiple crosses between the 
$h c f 106 /+$ parents of Table 1 and their $M u$-active siblings ( 4 sectored progeny in 114 hcf mutants, data not shown). In order to test whether $M u$-off plants might carry a "sectoring factor," pollen from the same $M u$ active ( $M u$-on) plant was used to pollinate four different $M u$-inactive (Mu-off) plants from the $h c f 106 / h c f 106$ Les $28 /+M u$-off line (Table 4). In these crosses, the number of hcf progeny was close to that expected (i.e., $100 \%$ penetrance). However, the proportion of hcf seedlings that were sectored differed between different crosses: cross 1 had 14 sectored progeny out of 40 hcf mutants, while cross 2 had only four sectored progeny out of 37 . These numbers are significantly different (at $P<1 \%$ using a $2 \times 2$ chi-square contingency test, or at $P<5 \%$, using Yates correction for small sample sizes (CAMPBell 1974)). This result is consistent with a "sectoring factor" being present in some $M u$-off plants, but not in others. However, as these crosses were spread over two days, some of the variation might be caused by tassel sectors in the $M u$-on parent that shed pollen on different days.

Whether or not sectoring was inherited from the $M u$-on or the $M u$-off parent, $M u$ activity was lost from all of the progeny derived by selfing sectored $h c f 106$ plants (Table 2 and data not shown). That is, the $M u D R$ elements in these lines only turn off, and very rarely, if at all, cycle back on. Thus, if there is a "sectoring factor," it must behave as a permanent modifier of $M u D R$ activity. Dominant inhibitory transposable elements are known in the $E n / S p m$ family in maize (CuYPERs et al. 1988), and in the $P$ element family in Drosophila (JACKSON et al. 1988; ROBERTSON and ENGELs 1989; MISRA and RIo 1990), and in each case they correspond to deletion derivatives of the autonomous form. MuDR deletion derivative elements are known to arise spontaneously at a high frequency in lines that have single $M u D R$ elements (D. Lisch, P. CHOMET and M. FreELING, manuscript submitted for publication), and multiple deletion derivatives were found in sectored Les $28 /+h c f 106 / h c f 106$ plants (Figure 5). It is possible that the putative "sectoring factor" is such a derivative element.

In a previous report, we described the pattern of sectors that arise in variegated $h c f 106$ plants, and concluded that it was non-random. This is substantiated by the fact that other patterns of variegation, like those induced by ring chromosome sister strand exchange (MCCLINTOCK 1938), or transposon excision (BossINGer et al. 1992), do not change with respect to the axis of the plant in such a predictable way. However, McClintock (1944) has described a pattern of variegation that is modified during plant growth in a manner similar to that described here. The chromatid breakage fusion bridge cycle occurs when a broken chromosome replicates, and the two sister chromatids fuse at their broken ends, resulting in an anaphase bridge. Fused chromosomes are broken and re-broken at each subsequent cy- tokinesis. In normal plants, this cycle is restricted to endosperm and gametophytic tissues. MCCLINTOCK described a few unusual plants in which the chromatid breakage fusion bridge cycle occurred in the sporophyte (the plant body) following entry of a single broken chromosome into the zygote. Cells undergoing this cycle in the sporophyte gave rise to clones that had lost chlorophyll pigmentation because of terminal deletions of the affected chromosome. However, the cycle spontaneously ceased during development, giving rise to sectors with only normal pigmentation. These sectors increased in size and frequency in the upper leaves, and were shown cytologically to comprise cells that were no longer undergoing chromatid fusion and breakage. This pattern was attributed to healing of the broken chromatid in cells that gave rise to the sectors (i.e., telomere addition).

This type of pattern might be explained if there were strong selection against mutant cells in the shoot apex (KLEKOWSK 1989). In the case of plants mosaic for $M u$ activity, we consider this explanation unlikely because (1) no alterations in relative growth of mutant and wildtype sectors were observed (such alterations have been observed for mitochondrial mutations when they sort out during development: HUNT and NEWTON 1991); and (2) many other mutations (including Les 28) show the same pattern of phenotypic suppression during development: the trans-acting nature of this suppression suggests that it represents changes in $M u$ activity rather than changes at individual loci. Instead, we favor the idea that the pattern has a developmental basis. It has been suggested, for example, that the observed loss of activity responds to developmental cues that regulate changes in shoot maturity and morphogenesis (POETHIG 1990). While this is certainly a plausible hypothesis, the clonal nature of the double mutant sectors suggests that loss of $M u$ activity occurs in individual cells early in development, rather than coordinately in later meristems. In order for their descendants to comprise the upper nodes of the plant, these cells must contribute to the central portion of the shoot meristem in the early embryo (POETHIG et al. 1986). In many respects, cells in this position resemble stem cell initials, although the population of cells that occupy the tip of the apex can shift during development (KLEKOWSKI 1989). Later in shoot development, labelling studies have shown that cells in the central zone of the apex have a characteristic morphology and relatively long cell cycle (reviewed in STEEves and Sussex 1989). One possibility is that the relatively long cell cycle in apical "stem" cells allows more time for the epigenetic modifications associated with loss of $M u$ activity to occur, before they are interrupted by DNA replication and cell division. Such epigenetic modifications might include heritable changes in chromatin structure, or de novo DNA methylation, which can be a relatively slow process in plants (VonGs et al. 1993) and animals (BESTOR et al. 1988). The same argument 
might also be applied to telomere addition in MCCLINTOCK's unusual plants (MCCLinTock 1944).

Thanks go to ANn Yonetani and Johanna O'Dell for technical assistance, Tim MULLIGAN for help with the plants, and Jim DuFfy for artwork. Kris Hardeman and Vicki Chandier kindly provided the $M u D R$ probe used in Figures 4 and 5 . We would like to thank Wolfgang Kammerer, Nigel Walker and Michael Freeling for communicating results regarding Les 27 , which is regulated in a similar way to Les 28. Also, thanks to V. SUNDARESAN and P. SPRINGER for comments on the manuscript, and V. Sundaresan, A. Barkan, D. Lisch and P. CHOMET for stimulating discussions. This work was supported by a grant from the Department of Energy Office of Basic Energy Sciences DE FG0291ER20047 (to R.A.M. and V.S.).

\section{LITERATURE CITED}

Banks, J. A., and N. V. Fedoroff, 1989 Patterns of developmental and heritable change in methylation of the Suppressor-mutator transposable element. Dev. Genet. 10: 425-437.

BARKAN, A., and R. A. MARTIENSSEN, 1991 Inactivation of maize transposon $M u$ suppresses a mutant phenotype by activating an outward-reading promoter near the end of $M u 1$. Proc. Natl. Acad. Sci. USA 88: 3502-3506.

Barkan, A., D. Miles and W. C. Taylor, 1986 Chloroplast gene expression in nuclear, photosynthetic mutants of maize. EMBO J. 5: 1421-1427.

BeNNETZEN, J. L., 1987 Covalent DNA modification and the regulation of Mutator element transposition in maize. Mol. Gen. Genet. 208: 45-51.

Bennetzen, J. L., W. E. Brown and P. S. Springer, 1988 The state of DNA modification within and flanking maize transposable elements, pp. 237-251 in Plant Transposable Elements, edited by $O$. E. NELSON. Plenum Press, New York.

Bennetzen J. L., P. S. Springer, A. D. Cresse and M. Hendprickx, 1993 Specificity and Regulation of the Mutator Transposable element system in maize. Crit. Rev. Plant Sci. 12: 57-95

Bestor T., A. Laudano, R. Mattaliano and V. Ingram, 1988 Cloning and Sequencing of a cDNA encoding DNA methyltransferase of mouse cells. J. Mol. Biol. 203, 971-983

BOEKE, J., 1989 Transposable elements in Saccharomyces cerevisiae, pp. 335-374 in Mobile DNA, edited by D. E. BERG and M. M. HowE. American Society for Microbiology, Washington, D.C.

Bossincer, G., M. MADDaloni, M. MotTo and F. SAlamini, 1992 Formation and cell lineage patterns of the shoot apex of maize. Plant J. 2: 311-320.

Brown, J., and V. Sundaresan, 1992 Genetic study of the loss and restoration of Mutator transposon activity in maize: evidence against dominant-negative regulator associated with loss of activity. Genetics 130: 889-898.

CAMPBELl, R. C., 1974 Statistics for Biologists Cambridge University Press

Chandler V. L., and K. Hardeman, 1992 The $M u$ elements of Zea mays. Adv. Genet. 30: 77-122

ChANDLER, V. L., and V. WALBot, 1986 DNA modification of a maize transposable element correlates with loss of activity. Proc. Nat1. Acad. Sci. USA 83: 1767-1771.

ChOMet, P. S., S. Wessler and S. L. DeLlaporta (1987) Inactivation of the maize transposable element Activator $(A c)$ is associated with its DNA modification. EMBO J. 6, 295-302.

Chomet P. S., D. Lisch, K. Hardeman, V. L. Chandler and M. Freeling, 1991 Identification of a regulatory transposon that controls the Mutator transposable element system in maize. Genetics 129 , 261-270

CoE, E. H. JR., 1961 A test for somatic mutation in the origination of conversion-type inheritance at the $B$ locus in maize. Genetics 53, 1035-1063

Cuypers, H., S. Dash, P. A. Peterson, H. Saedler and A. Gierl, 1988 The defective En-1102 element encodes a product reducing the mutability of the En/Spm transposable element system of Zea mays. EMBO J. 7: 2953-2960.

Fedoroff, N. V., 1983 Controlling elements in maize, in Mobile Genetic Elements. Academic Press, New York.
FEDoroff, N. V., 1989 Maize transposable elements, in Mobile DNA, edited by D. E. BERG and M. M. HowE. American Society for Microbiology, Washington D.C.

Frey, M, J. ReIneCKe, S. Grant, H. Saedler and A. GierL, 1990 Excision of the En/Spm transposable element of Zea mays requires two element-encoded proteins. EMBO J. 9: 4037-4044.

GIERL, A., 1990 How maize transposable elements escape negative selection. Trends Genet. 6: 155-158

Grant, S. R., A. Gierl and H. Safdler, 1990 En/Spm encoded tnpA protein requires a specific target sequence for suppression. EMBO J. 9: 2029-2035.

Gruenbaum Y., T. Naveh-Many, H. Cedar and A. Razin, 1981 Sequence specificity of methylation in higher plant DNA. Nature 292, $860-863$

Hahn, S., S. Buratowski, P. A. Sharp and L. Guarente, 1989 Isolation of the gene encoding the yeast TATA binding protein TFIID: a gene identical to the SPT 15 suppressor of Ty element insertions. Cell 58: 1173-1181.

HaKe, S., 1992 Unravelling the knots in plant development. Trends Genet. 8: 109-114.

HAKE S., and M. FreELING, 1986 Analysis of genetic mosaics shows that the extra epidermal cell divisions in Knotted mutant maize plants are induced by adjacent mesophyll cells. Nature 320: 621-623

Hershberger R. J., C. A. WARREN and V. Walbot, 1991 Mutator activity in maize correlates with the presence and expression of the $M u$ transposable element Mu 9. Proc. Natl. Acad. Sci. USA 88: 10198

HOLuDAY, R., 1987 The inheritance of epigenetic defects. Science 238: $163-170$.

HunT, M. J., and K. J. Newton, 1991 The NCS3 mutation: genetic evidence for the expression of ribosomal protein genes in Zea mays mitochondria. EMBO J. 10: 1045-1052.

JACKSON, M. S., D. M. BLACK and G. A. DOVER, 1988 Amplification of $K P$ elements associated with the repression of hybrid dysgenesis in Drosophila melanogaster. Genetics 120: 1003-1013.

JoHrI, M. M., and E. H. COE JR., 1982 Genetic approaches to meristem organization, pp. 301-310 in Maize for Biological Research, edited by W. F. SHERIDAN. University of North Dakota Press, Grand Forks.

Kı.ekowsKI, E., JR. 1989-Mutation. Developmental Selection and Plant Evolution. Columbia University Press, New York.

Langdale, J. A., B. Lane, M. Freeling and T. Nelson, 1989 Cell lineage analysis of maize bundle sheath and mesophyll cell. Dev. Biol. 133: $128-139$.

LOWE B, J. MATHERv and S. HAKE, 1992 Active Mutator elements suppress the Knotted phenotype and increase recombination at the Kn1-O tandem duplication. Genetics 132: 813-822.

Martienssen, R. A., A. Barkan, M. Freeling and W. C. Taylor, 1989 Molecular cloning of a nuclear gene in maize involved in thylakoid organization, and its regulation by Robertson's mutator. EMBO J. 8: 1633-1640.

Martienssen, R. A., A. Barkan, W. C. Taylor and M. Freeling, 1990 Somatically heritable switches in DNA modification of $M u 1$ transposable elements in maize revealed by a suppressible mutant. Genes Dev. 4: 331-343.

Masson, P., R. Surosky, J. A. Kingsbury and N. V. Fedoroff, 1987 Genetic and molecular analysis of the Spm-dependent a-m 2 alleles of the maize $a$ locus. Genetics 177: 117-137.

McCarty D., C. CARSON, M. LazAR and S. Simonds, 1989 Transposable element induced mutations of the $v p 1$ gene in maize. Dev. Genet. 10: 473 .

McCuntock, B., 1938 The production of homozygous deficient tissues with mutant characteristics by means of the aberrant mitotic behaviour of ring-shaped chromosomes. Genetics 23: 315-376.

MCClintock, B., 1944 Maize Genetics. Carnegie Inst. Washington Year Book 43: 127-135.

McClinTock, B., 1958 The Suppressor-mutator system of control of gene action in maize. Carnegie Inst. Washington Year Book 57: $415-429$.

MCCLINTOCK, B., 1964 Aspects of gene regulation in maize. Carnegie Inst. Washington Year Book 63: 592-602.

MCCunTOCK, B., 1965a Components of action of the regulators Spm and $A c$. Carnegie Inst. Washington Year Book 64: 527-536.

McCuntock, B., 1965b The control of gene action in maize. Brookhaven Symp. Biol. 18: 162-184.

McCunToCK, B., 1968 The states of a gene locus in maize. Carnegie Inst. Washington Year Book 66: 20-28. 
MaDaniel, C. N., and R. S. Poethig, 1988 Cell-lineage patterns in the shoot apical meristem of the germinating maize embryo. Planta 175: 13-22.

MisRA, S., and D. C. Rio, 1990 Cytotype control of Drosophila P element transposition: the $66 \mathrm{kd}$ protein is a repressor of transposase activity. Cell 62: 269-284.

Neuffer M. G., and O. H. CalverT, 1975 Dominant disease lesion mimics in maize. J. Hered. 66, 265-270

Parkhurst, S. M., D. A. Harrison, M. P. Remington, C. Spana R. L. Kelley et al., 1988 The Drosophila su(Hw) gene, which controls the phenotypic effect of the gypsy transposable element, encodes a putative DNA-binding protein. Genes Dev. 2: 1205-1215.

Peterson, P. A., 1966 Phase variation of regulatory elements in maize. Genetics 54: 249-266

PoETHIG, R. S., 1990 Phase change and the regulation of shoot morphogenesis in plants. Science 250: 923-930

PoethiG, R. A., E. H. Coe, JR., and M. M. Johri, 1986 Cell lineage patterns in maize embryogenesis: a clonal analysis. Dev. Biol. 117: 392-404.

Qin M., D. S. Robertson and A. Elllingboe, 1991 Cloning of the Mutator transposable element $M u A 2$ a putative regulator of somatic mutability of the a1-mum2 allele in maize. Genetics 129: 845-854.

RoBertSon, D. S., 1980 The timing of $M u$ activity in maize. Genetics 94: $969-978$.

RoBertson, D. S., 1983 A possible dose-dependent inactivation of mutator $(M u)$ in maize. Mol. Gen. Genet. 191: 86-90.

RoBERTSON, D. S., 1986 Genetic studies on the loss of $M u$ mutator activity in maize. Genetics 113: 765-773.

Robertson, H. M., and W. R. Engels, 1989 Modified $P$ elements that mimic the $\mathrm{P}$ cytotype in Drosophila melanogaster. Genetics 123: 815-824.
Ruth.eDGe, B. J., M. A. Mortin, E. Schwarz, D. ThIERRYMieg and M. MESELSON, 1988 Genetic interactions of modifier genes and modifiable alleles in Drosophila melanogaster. Genetics 119: 391-397.

SchlaPPI M., D. SMITH and N. V. FedOROFF, 1993 TnpA trans-activates methylated maize Suppressor-mutator transposable elements in transgenic tobacco. Genetics 133: 1009-1021.

Schwarz D., 1989 Gene controlled cytosine demethylation in the promoter region of the $A c$ transposable element in maize. Proc. Natl. Acad. Sci. USA 86: 2789-2793.

Schwarz-Sommer, Zs., A. Gierl, R. B. Klosgen, U. Wienand, P. A. PeTERSON et al., 1984 The Spm (En) transposable element controls the excision of a 2-kb DNA insert at the $w x^{m-8}$ allele of Zea mays. EMBO J. 3: 1021-1028.

Schwarz-Sommer, Z., N. Shepherd, E. TAGke, A. GierL, W. Rohde et al., 1987 Influence of transposable elements on the structure and function of the $A 1$ gene of Zea mays. EMBO J. 6: 287-294.

SELKER, E. U., 1990 DNA methylation and chromatin structure: a view from below. Trends Biochem. Sci. 15: 103-107.

Steeves, T., and I. Sussex, 1989 Patterns in Plant Development. Cambridge University Press, Cambridge.

Vongs A., T. Kakutani, R. A. Martienssen and E. J. Richards, 1993 Arabidopsis thaliana DNA methylation mutants. Science 260: $1926-1928$.

WALBOT, V., 1986 Inheritance of Mutator activity in Zea mays as assayed by somatic instability of the $b z 2-m u l$ allele. Genetics 114: 1293-1312

WALBOT, V., 1992 Reactivation of Mutator transposable elements of maize by ultraviolet light. Mol. Gen. Genet. 234: 353-360

Williams, J. A., S. S. PAPPU and J. B. BELL, 1988 Suppressible Pelement alleles of the vestigial locus in Drosophila melanogaster. Mol. Gen. Genet. 212: 370-374.

Communicating editor: B. BURR 